S. K. Moldabayev ${ }^{1}$, orcid.org/0000-0001-8913-9014, O. O. Sdvyzhkova ${ }^{2}$, orcid.org/0000-0001-6322-7526, D.V. Babets ${ }^{2}$, orcid.org/0000-0002-5486-9268, O.S. Kovrov ${ }^{2}$, orcid.org/0000-0003-3364-119X, T. K. Adil ${ }^{1}$, orcid.org/0000-0002-3019-4286
1 - Satbayev University, Almaty, the Republic of Kazakhstan 2 - Dnipro University of Technology, Dnipro, Ukraine, e-mail: sdvyzhkova.o.o@nmu.one

\title{
NUMERICAL SIMULATION OF THE OPEN PIT STABILITY BASED ON PROBABILISTIC APPROACH
}

Purpose. To identify development regularities related to a stress-strain state and stability of the open pit walls while mining the steeply inclined iron-ore body at various stages of mining considering deterministic and stochastic components of the rock mass structural heterogeneity.

Methodology. Numerical 3D simulation of the rock stress-strain state; application of the "strength reduction" procedure to determine a safety factor, taking into account the rock mass heterogeneity based on a stochastic model.

Findings. The distribution of maximum shear deformations and displacements within the rock mass, making up the pit wall, has been obtained. Potential slide surfaces and safety factors have been determined at various stages of the inclined ore body mining. The effect of the rock mass structure on the pit wall stability has been estimated. A comparison of calculations based on the $3 \mathrm{D}$ and 2D models has been carried out. The correction coefficient has been obtained, which allows using the 2D model for multivariate calculations. The relationship of safety factor versus the overall slope angle has been developed.

Originality. It has been proved that pit walls retain their stability (the stability factor (SF) is not less than 1.27) while mining the steeply inclined ore body with the transverse panels from top to bottom within each newly cut layer, despite the increasing depth of mining. It is shown that modeling of the real geological structure of a three-dimensional rock mass area factors into the decrease in (by $7 \%$ ) the safety factor in comparison with the results of the homogeneous model. A probabilistic-statistical approach has been proposed to consider the heterogeneity of the rock mass and avoid unreasonably optimistic forecasts of the pit wall stability. It is shown that $3 \mathrm{D}$ modeling gives $\mathrm{SF}$, which differs by $8 \%$ from the values obtained in the $2 \mathrm{D}$ model. This allows substantiating the correction coefficient to improve the 2D modeling results.

Practical value. The regularity of changes in the pit wall stability has been determined depending on the overall pit slope angle in terms of mining-geological and mining-technical conditions of the Kachar deposit, taking into account the real rock heterogeneity.

Keywords: ore mining, open pit, wall stability, stochastic environment, numerical simulation, rock stress-strain state, safety factor

Introduction. Ukraine and Kazakhstan are leaders in ironore deposits being developed intensively by open-pit mining. Modern iron-ore open pits have numerous problems concerning the peculiarities of mining steeply inclined seams, increasing mining depth as well as growing risks of pit wall instability and consequent landslide processes [1]. Slope control in open pits is a complex problem, whose solution includes first of all mining and technological issues on rational procedure and intensity of mining operations owing to the use of certain equipment types.

The main principles of the control of open pit walls are as follows:

- pit walls should ensure safe (for people and equipment) mining operations;

- pit slopes should provide expediency of the deposit development.

In terms of open-pit mining the steeply-dipping deposits by the round-shape open-pit fields, development of the rock overburden slopes and ore by transverse panels from top to bottom within each newly cut steeply-dipping layer is one of the most efficient solutions [2]. In this context, high-productive use of the earthmoving and motor complexes as well as the required intensity of mining operations can be reached by elimination of dead-end dump turn on wide sites, more qualitative rock crushing in terms of multi-row delay-action blasting, and reduced rock movement after blasting into the minedout space. High technical and technological indices are ob-

(C) Moldabayev S. K., Sdvyzhkova O. O., Babets D. V., Kovrov O.S., Adil T. K., 2021 tained by reducing premature widening of the walls of deep and ultradeep open pits. However, before the approach of mining operations to the limiting surface contour of deep open pits, the height of steeply inclined layers increases; that will intensify the risk of rock mass instability in terms of the greater thickness of the overburden loose rocks (up to $160 \mathrm{~m}$ ).

Due to that fact, a problem arises concerning both the prognosis of a stress-strain state of the rock mass at different mining stages and estimation of the pit walls stability taking into consideration mining and geological features of the deposit as well as mining and technical conditions of the ore deposit development.

Literature review. The open pit depth is constantly growing; thus, stability of the slopes under development is of great importance to optimize the resulting slope angle by its maximum increase with observance of the safe mining standards. The stability of the open pit slopes in terms of large angles is evaluated by a combined analysis involving the methods of limit equilibrium and numerical simulation [3], i.e. by using such systems as MSARMA ("Evaluation and analytical system for slope stability analysis") [4], and so on.

Numerous cases of slope collapse recorded in copper, gold, iron, diamond, lead, zinc, and platinum open pits all over the world make the researchers develop their hazard assessment systems where main mining components are analyzed and risks are determined based on such algorithms as discriminatory analysis, "certainty ellipses" construction, and others [5].

A complex analysis of the slope stability with the use of radars (the SAR system) was proposed in [6] to monitor ironore pit walls in the province of Carajás (the Amazon region). 
Paper [7] describes positive practices of applying a combination of methods including Google Earth and field surveys to study a process of wall destruction in the iron-ore open pit.

Preliminary evaluation of the pit wall stability may be performed based on physical modeling. A physical model helps to visualize a process of slope collapse and assess the main geometrical parameters of the landslide process with the following prognosis of possible geohazard in a real open pit $[8,9]$.

A large body of research focuses on the high probability of dramatic deformation processes within the open pit walls, which is stipulated by the composition of several unfavorable factors. Paper [10] shows that unpredictably massive deformations within the pit wall occur due to the effects of physical weathering that has stipulated reduced soil stability and the development of fissures along with the weak layer. The authors of the paper [11] indicate the complicated conditions of lignite development in Greece due to the fact that within the recent decades the open pits have become larger and deeper (down to $200 \mathrm{~m}$ ); as a result, currently, they are more difficult to control.

Modeling the critical states of the pit walls is similar in many ways to the analysis of a landslide development [12]. The authors of the paper [13] reveal a problem of landslide modeling in soft clays. Reduction of clay stability in terms of plastic deformation results in the fact that breaking is irreversible so that the soil shears within a small slope can cause a series of regressive failures and result in a sudden catastrophic landslide.

Authors of all the aforementioned papers are unanimous in the idea that mathematical simulation is an important constituent part of geotechnical studies. Modern numerical methods make it possible to consider the enumerated factors determining slope stability. The results of numerical simulation by both a method of finite and discrete elements and a method of finite differences are discussed. The authors of the early mentioned paper [12] point out that successful forecast of landslides in clays requires reliable numerical simulation, being capable of reflecting extreme material deformations. The positive experience of finite element modeling of the deformation processes (using RS3 program) was demonstrated while reconstructing the landslide in Saint-Jude, Quebec, Canada [13]. Paper [14] shows that transportation of overburden and mineral raw materials in terms of open pits is one of the most complicated and costly processes. Consequently, the design of traffic arteries also involves numerical modeling to minimize costs for long-term construction and maintenance. The FEM analysis of a stressstrain state of the natural or artificial slope allows not only forecasting the potential slip surface but also developing certain methods to ensure the stability of a geotechnical object [15].

In this context, most researchers state that the adequacy of the modeling is guaranteed by the initial data reliability, first of all, relative to mechanical characteristics of lithological differences.

Thus, the authors of the paper [16] note that the assessment of shear strength is of critical importance for stability analysis. However, the limited availability of direct measurements in engineering practice makes the evaluation of real soil properties quite difficult. That very circumstance is highlighted by the authors of the paper [17]. It is stressed that due to the difficulty of identifying mechanical properties of weak seams within the pit walls, it is necessary to carry out regressive analysis in combination with the data on rock displacement monitoring.

Unsolved aspects of the problem. The represented example demonstrates that stabilization of slopes and open pit walls is determined to a large extent by the adequate prognosis of geomechanical processes under certain geological conditions. In this context, mathematical, in particular, numerical simulating the stress-strain state (SSS) of the rock mass is quite an efficient tool. Nevertheless, even in case of using powerful and multi-functional software complexes for creating 3D models, the reliability of the initial data is the compulsory condition. The mechanical properties of rocks are such obligatory data apart from geometrical parameters of the areas and loading conditions. In this context, there is always some uncertainty in the determination of those characteristics stipulated by the considerable rock mass heterogeneity. To date, there is no unambiguous approach to consider the structural heterogeneity of the rock mass, in particular, the systems of joints, while numerical simulating the rock stress-strain state and assessing the stability of the pit walls.

The purpose is to identify regularities in changes of pit wall stability at different stages of technological operations while mining steeply-inclined layers based on 3D modeling of the rock state considering the rock mass structural heterogeneity. The research was carried out in terms of the Kachar magnetite-ore deposit (Kazakhstan) where the problem of pit stability is quite acute due to the intense deepening of mining.

Description of the research object. The Kachar magnetiteore deposit belongs to the major iron-ore belt of Turgay trough. Engineering and geological conditions of the deposit development are complicated due to the considerable thickness of unconsolidated sediments as well as weak surfaces in hard rock directed towards the mined-out space. The thickness of the unconsolidated sediments varies from 130 to $200 \mathrm{~m}$, being $160 \mathrm{~m}$ on average. Meso-Cenozoic deposits are represented by sedimentary rocks of different ages: clay loams, clays, sands, argillaceous opokas and sandstones, and conglomerates. Below, clays of the bedrock weathering layer occur; their thickness reaches up to $30 \mathrm{~m}$, being $5-10 \mathrm{~m}$ on average. Within certain areas, there is no clay of the weathering layer at all. A complex of hard and medium-hard Paleozoic rocks is represented by sedimentary, effusive, sedimentary-igneous, and metasomatic rocks (porphyrites, aphyrites, tuffs, tuffites, tuff sandstones, limestones, and ores of magnetite composition). There are also joint systems of different orientations.

Mining of rock overburden and steeply inclined ore layer from the top to bottom means that the mining depth increases at each stage of operations; thus, the resulting slope angle increases as well. Consequently, safer and more efficient mining under the specified conditions requires adequate estimation of the pit wall stability.

Methods. To identify the rock stress-strain state, a well approved numerical method of finite elements is used implemented in the licensed software RS3 (Rocscience). The computational scheme (Fig. 1, $a$ ) includes a wall part made up of hard rock as this is the area which stability is of special interest for the development of technical solutions. The main part of the rocks involved in the deformation process is represented by ore, limestones, and tuffs. The layers of those rocks are modeled according to the data on their thickness and parameters of bedding. Digital 3D representation of the ore body at each mining stage is performed in the software SURPAC, which files are imported in the RS3 code.

While simulating a three-dimensional area of the rock mass, boundary conditions are determined by the fixation of the model displacements: plane $X Y$ (bottom of the model) is fixed along the axes $X, Y$, and $Z$; plane $Y Z$ is fixed along the axes $X$ and $Y$, and plane $X Z$ is fixed along the axis $Y$.

A finite-element mesh of the model (Fig. 1, $b$ ) is obtained by the uniform division of the area into 10-apex tetrahedrons. The number of elements for the model represented below is 267595 .

The pit wall stability is assessed based on the elastoplastic model of the rock mass and the Coulomb-Mohr failure criterion

$$
\tau=c+\sigma_{n} \operatorname{tg} \varphi
$$

here $\tau$ is tangential stress (shear stress) and $\sigma_{n}$ is normal stress. Internal friction angle $\varphi$ and cohesion c are the strength characteristics included in the strength conditions.

The safety factor is the most significant result of the numerical simulation indicating the possibility of wall operation in terms of the present geometrical parameters

$$
F=\frac{\text { shear strength }}{\text { shear force }} .
$$



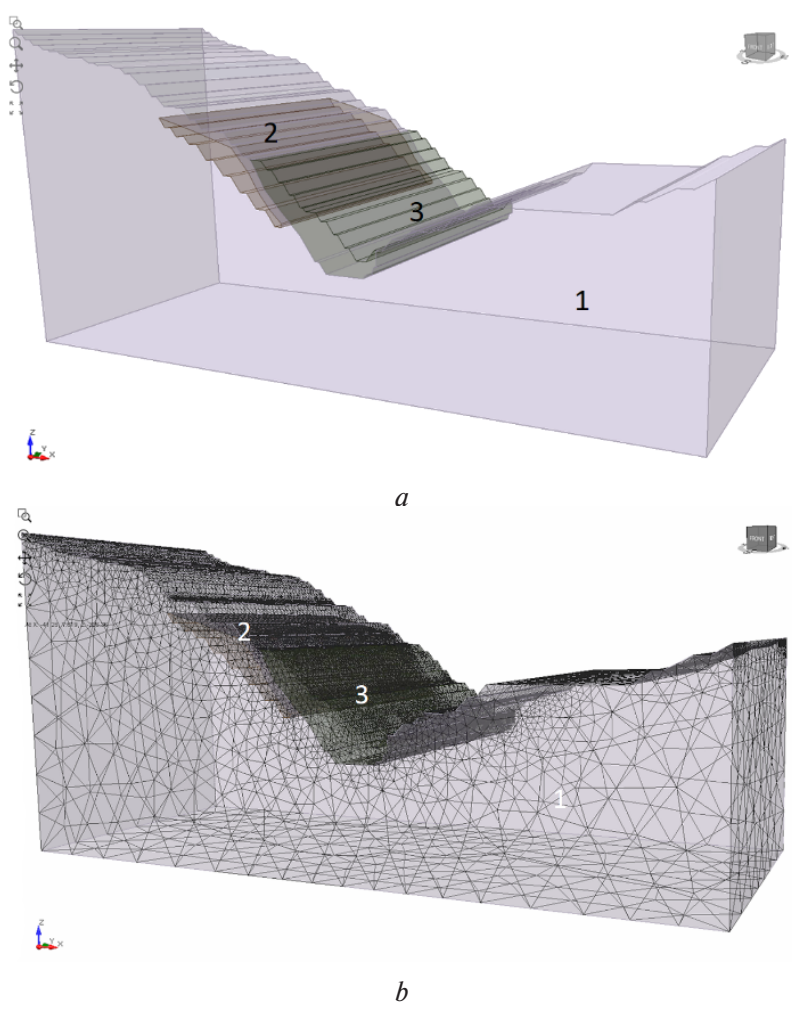

Fig. 1. The area geometry corresponded to the $11^{\text {th }}$ (at the moment - final) stage of the ore body mining within the considered deposit area:

$a$ - computational scheme; $b$ - finite-element model; 1 - main rock mass (limestones); 2 - tuffs; 3 - ore deposit

To determine the value, a well-adapted "strength reduction" procedure [17] is used in the RS3 code. If a slope is in the equilibrium state, then the Coulomb-Mohr failure criterion (1) can be represented as follows

$$
\frac{\tau}{F}=\frac{c}{F}+\frac{\tan \varphi}{F} .
$$

Thus, the slope stability factor is the value $F$, by which the initial shear strength parameters must be divided to bring the slope to collapse. Then, strength characteristics of shear resistance $c_{f}^{\prime}$ and $\varphi_{f}^{\prime}$, at which a slope loses its stability, can be written in the form

$$
\begin{gathered}
c_{f}=\frac{c}{F} ; \\
\varphi_{f}=\arctan \left(\frac{\tan \varphi}{F}\right) .
\end{gathered}
$$

Such interpretation makes it possible to determine the stability factor by sequential reduction of real stability characteristics of the rocks, making up the slope, by $F$ times up to the "reduced" (factorized) values $c_{f}$ and $\varphi_{f}$, at which stability of the slope with the preset geometry becomes impossible, i.e. the slope collapse takes place.

The initial values of internal friction angle $\varphi$ and adhesion $c$ play an important role in this procedure as they are usually determined by a geological service by testing the rock samples under laboratory conditions according to well-known methodologies. However, there is a known fact that there are certain dissimilarities between the properties of real rocks and the ones of the samples under testing [18]. That is stipulated by the considerable heterogeneity of rocks occurring in the real rock mass, though it is not manifested during the sample testing. The mentioned dissimilarity may be considered by introducing the structural coefficient determined on the basis of a probabilistically statistic approach [19] .
It has been noted before that according to the data by the geological service of an open pit, there is certain jointness of different degrees within the rock mass. Paper [20] indicates the prevailing role of jointness in reducing rock strength and the difference of the heterogeneous mass strength from one of the rock samples tested in a laboratory. Since the strength properties of rocks determine directly the pit wall stability and are the most important initial data to simulate the rock mass state, special attention is paid to the consideration of the aforementioned difference (scale effect) in the mentioned studies.

There are different methods to consider rock mass heterogeneity and its effect on mechanical properties. Most of them are based on the generalization of laboratory tests of samples and in-situ observations, which were further implemented in different rating classifications. The rating systems help to identify the rock mass quality depending on the availability of various features of heterogeneity, i.e. the ones of jointness.

We propose a probabilistic approach, based on the statistic theory of strength to consider structural features of rocks.

Consideration of rock heterogeneity based on a probabilistic approach to the strength property assessment. The sample with $\mathrm{n}$ values of the studied mechanical characteristic $X$ is the result of rock testing. The average value $\bar{x}$ is the statistic estimation of the theoretical mean $x_{m}$. Assume a priori that the real mean $x \mathrm{~m}$ of the characteristic $X$ differs from the average sampling $\bar{x}_{m}$ due to heterogeneity of a real rock or soil mass, for which the samples under testing are structural elements. This dissimilarity is characterized by the structural coefficient $k_{c}$ being equal to

$$
k_{c}=\frac{x_{m}}{\bar{x}} .
$$

We will also consider that the strength of the heterogeneous rock mass is less than the one of the rock samples (structural elements of the rock mass). Indeed the probability to identify some defects within the large volume is higher; thus, the strength characteristic of a larger body is lower, i.e. one can assume that $x_{m}$ is the least value of all the values of the given mechanical characteristic, and inequality $X \geq x_{m}$ takes place. The probability of such inequality $P$ is determined by the distribution function $F(x)$ of the sign under analysis $X$

$$
P\left(X \geq x_{m}\right)=1-F\left(x_{m}\right)=P_{0} .
$$

Probability $P_{0}$ characterizes a level of the object significance; it is preset a priori. Then, a true value of the mechanical characteristic $x_{m}$ will be determined from equation (3), whose concrete form depends on the hypothesis about the type of function distribution of structural elements strength $F(x)$. In [18], the authors propose to take normal or logarithmically normal distribution of probabilities as a stochastic model of strength of structural elements of the rock mass. In terms of the current research, based on the studies on different soil types, we propose to consider the strength characteristic, i.e. cohesion and internal friction, to be distributed according to the uniform law. Contrary to the normal one, this law assumes a considerable (up to $60 \%$ ) spread of the characteristic values relative to the mean, which is peculiar for the jointed soil or rock.

In case of the uniform law the distribution function looks like

$$
F(x)=\frac{x-a}{b-a} .
$$
then

Taking into consideration (3), we obtain $P_{0}=1-\frac{x_{m}-a}{b-a}$,

$$
x_{m}=(b-a)\left(1-P_{0}\right)+a .
$$

It is known that in case of uniform distribution, theoretical moments of distribution - the mean $M(x)$, standard deviation $\sigma(x)$, and relative variation $\eta$ are equal to

$$
M(x)=\frac{b+a}{2} ; \quad \sigma(x)=\frac{b-a}{2 \sqrt{3}} ; \quad \eta=\frac{\sigma}{\bar{x}}=\frac{b-a}{\sqrt{3}(b+a)} .
$$


Having divided both parts of equation (4) by $M(x)$ and considering (2), we get

$$
k_{c}=\sqrt{3} \eta\left(1-2 P_{0}\right)+1 .
$$

It is clear that the structural coefficient $k_{c}$ depends first on relative variation $\eta$ and characterizes a level of environment heterogeneity; secondly, it depends on probability $P_{0}$, which characterizes a level of object significance.

Thus, while using strength characteristic $X$ (cohesion $C$ and angle of internal friction $\varphi$ ) in geomechanical calculations, their natural range should be considered by introducing structural $k_{c}$ into the corresponding formula

$$
x_{m}=k_{c} \bar{x} .
$$

At this stage, since there are no data on the parameters of joint systems, relative variation is taken as the one equal to value $\eta=0.15$; probability of determination of the structural coefficient was taken as the one equal to $P_{0}=0.9$. Then, according to (5), the structural coefficient is $k_{c}=0.8$. The initial strength characteristics (cohesion and internal friction angle) are reduced according to (6) and represented in Table.

Results. Finite element analysis of the rock stress-strain state with the use of the elastoplastic constitutive model and the Coulomb-Mohr failure criterion allows singling out zones of the greatest rock displacements (Fig. 2). Practically, a zone of maximum displacements covers an ore layer, which has the least strength characteristics. The calculations are performed for 11 planned stages of ore body mining within the considered open pit field (western slope). Each stage involves changes in the area geometry (changes in the resulting slope angle) and rock mass structure (changes in the thickness of ore and rock layers). However, the features of displacements remain the same.

The safety factor of the open pit slope is the most significant result indicating the possibility of safe mining in terms of the specified geometrical parameters of walls. As it has been mentioned before, a "strength reduction" method is used to identify that value. A procedure of step-by-step stability reduction while using numerical methods, in particular FEM, is of special efficiency. Its essence is in the following: the solution is taken in a stage-by-stage way; at each solution stage the strength characteristics are reduced with a certain pitch and the rock strain-stress state is determined. The process continues up to the moment when a finite-element model experiences its collapse. Mathematically, it means the divergence of the iteration process in a numerical solution. When the algorithm cannot converge within the maximum number of operations preset by a user, one cannot obtain the distribution of stresses, which satisfy both the Coulomb-Mohr failure criterion (1) and global equilibrium conditions. If the algorithm cannot meet these conditions, it is considered that the model "failure" takes place. Thus, the divergence of the iteration process in the numerical solution means physically the slope collapse. A value of a strength reduction factor, in terms of which collapse in the solution occurs, is taken as the slope safety factor $F$.

The final result of a "strength reduction" procedure for the area represented in Fig. 1 ( $11^{\text {th }}$ stage of mining) and the rocks with properties given in Table 1 is the factor of slope stability $F$ (strength reduction factor) equal to 1.27. A region of maximum shear strains is shown for the same stage (Fig. 3). This region determines a potential slip surface, which can take place hypothetically in terms of the strength characteristics reduction by $F$ times.

It should be noted that the model-based representation of real contours of the ore body and rock layers, experiencing their changes at each mining stage, is quite a labor-intense process. That is why initially a homogeneous rock mass was simulated; moreover, the ore properties, having the least strength properties, were assigned to the material under modeling. The safety factor for such a homogeneous model at the $11^{\text {th }}$ stage of mining is 1.35 . It means that even though there are more stable layers (limestone, tuff) in the layered model (Fig. 1), the safety factor obtained on its basis and being equal to 1.27 is by $7 \%$ less. The pattern of maximum shear strains (Fig. 3) shows that the potential slip surface goes exactly along the boundary of ore and rock layers. Thus, consideration of the real rock mass structure represents less optimistic and more reliable stability evaluation, confirming additionally the efficiency of a finite element analysis, whose advantage is in the possibility to model all the features of rock mass structure and texture.

Above, it has been highlighted that the resulting slope angle, changing with the advance of operations, is the main geometrical parameter of the open pit wall. Along with the deepening of mining, the resulting angle increases, and correspondingly, the safety factor (SF) of a slope experiences its reduction as well (Fig. 4).

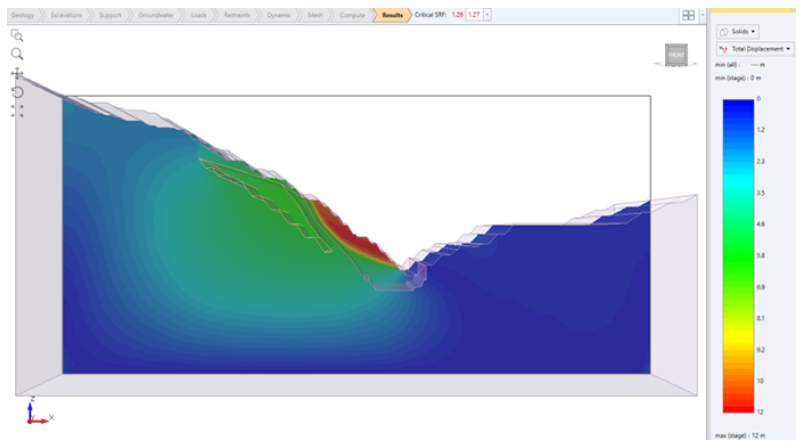

Fig. 2. Zone of maximum total displacements (in red) at the $11^{\text {th }}$ stage of mining

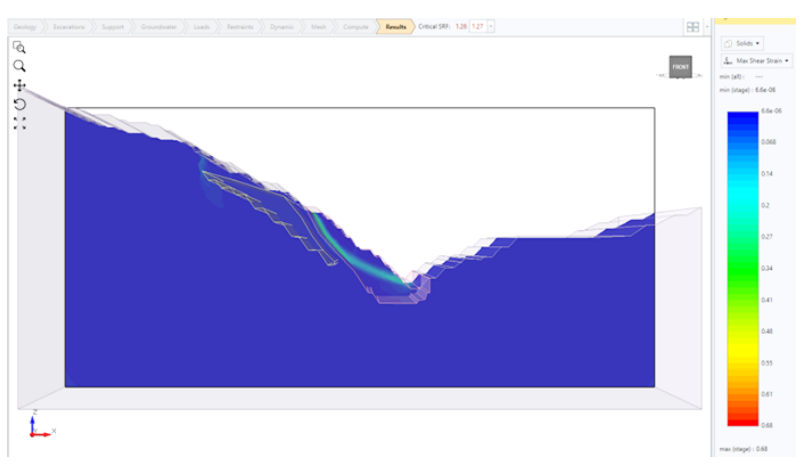

Fig. 3. Area of maximum shear strains (potential slip surface at the $11^{\text {th }}$ stage of mining)

Rock properties

\begin{tabular}{|l|c|c|c|c|c|}
\hline \multirow{2}{*}{ Rock } & \multicolumn{2}{|c|}{ Cohesion, KPa } & \multirow{2}{*}{ Average gravity, $\mathrm{t} / \mathrm{m}^{3}$} & \multicolumn{2}{c|}{ Internal friction angle, degree } \\
\cline { 2 - 3 } \cline { 5 - 6 } & average & taking into consideration $k_{c}$ & & average & taking into consideration $k_{c}$ \\
\hline Limestone & 568 & 450 & 25.0 & 34 & 27 \\
\hline Tuff & 416 & 330 & 26.8 & 41 & 33 \\
\hline Ore deposit & 366 & 290 & 33.0 & 39 & 31 \\
\hline
\end{tabular}




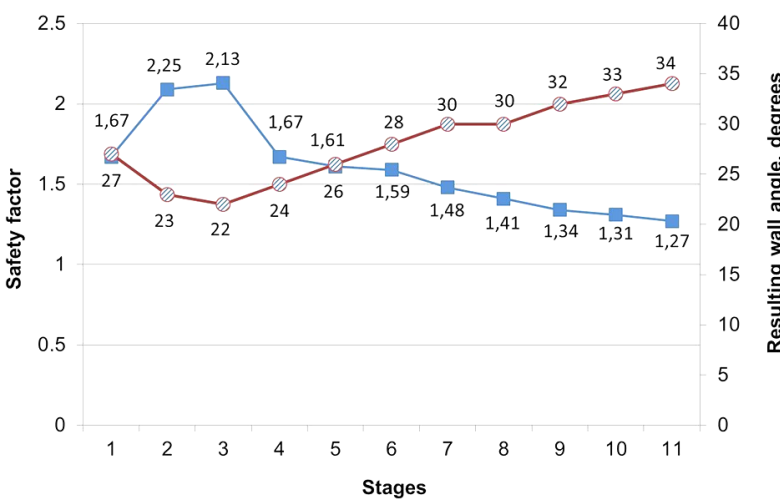

Fig. 4. Changes in the resulting slope angle at the stages of mining and corresponding values of the safety factor

The general tendency of decreasing the pit wall stability in terms of increasing slope angle is known quite well as it is based on the idea of limit equilibrium of particles on the inclined surface. However, the quantitative interpretation obtained in this research is the practical result that provides assessing certain changes in the stable state of the pit wall at different stages of mining under real geological and technical conditions. Each mining stage involves the measurement of the mined-out space geometry that can change the resulting slope angle. Since the monotonous increase in a slope angle at each stage of the pit deepening was not observed (Fig. 4), the calculations did not record any monotonous decrease in SF as well.

The loop-like nature of the graph in Fig. 4 stresses the expediency of finite element simulation in each specific case as the numerical method helps to consider all the geometry features of the area under analysis and structures of the environment being modeled. The indicated factors determine directly the slope stability, which is demonstrated by the relationship.

The SF (equal to 1.27) obtained at the final $\left(11^{\text {th }}\right)$ stage is the admissible one in terms of open-pit mining; however, it shows that along with the deepening of operations, the slope state approaches the limit one. If there is more intense jointness, the bearing capacity of rocks will experience certain changes. The proposed approach allows considering this circumstance by recalculating the structural coefficient at the expense of increasing relative variation of strength characteristics. The latter is determined depending on the distance between joints according to the methods proposed in [18].

Thus, the proposed totality of the methods is an important component of designing safe technological systems for ore mining, which is of special significance under complicated geological conditions, i. e. while developing steeply inclined seams.

It should be noted that 3D-based calculations are rather costly from the viewpoint of calculation time and necessary parameters of the computer operating system. The alternative here is to use a two-dimensional computational system to implement FEM for the analysis of one of the slope plane sections. In this context, one should remember that in this case, a plane deformation hypothesis is not true. Nevertheless, reduction of the problem dimension has its advantages while performing considerable calculation series.

For comparison, the calculations are performed for the plane section of the area in terms of specification of the same rock mass structure and the same properties of the rock layers. In general, a pattern of stress distribution, strains, and displacements (Fig. 5) coincide with the one obtained in the complete three-dimension model. The calculations are carried out for all 11 stages of ore body mining. In particular, in case of the $11^{\text {th }}$ (final) mining stage, the SF based on the plane model is 1.17 (as opposite to 1.27 in a three-dimensional model). The difference is caused by the previously mentioned model of plane deformation, i. e. with the neglect of one of the components of complete stress and strains tensors in the 2D model.

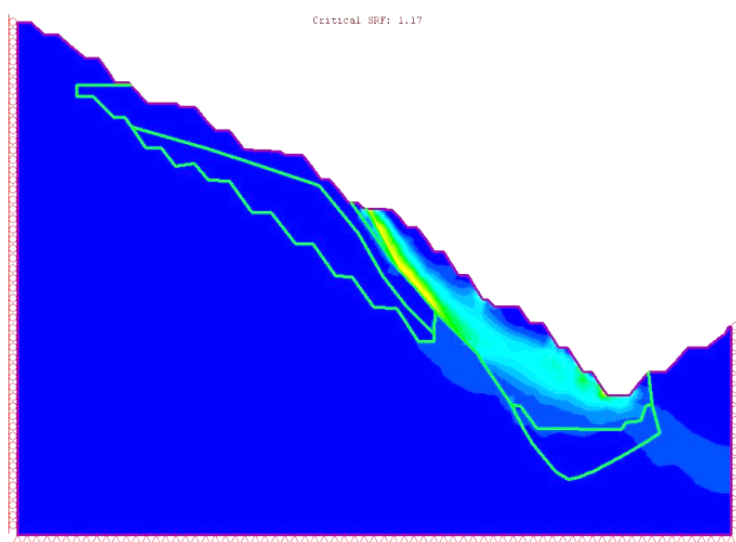

Fig. 5. Potential slip curve obtained in the $2 D$ model ( $11^{\text {th }}$ stage of mining)

The obtained difference can be used as a correction coefficient in case if the studies mean multifactor data analysis and large-scale computational experiment. In such situations, two-dimensional models can be used; however, the results should be corrected taking into consideration the coefficient, which we have substantiated by averaging on the basis of 24 performed variants of comparative calculations

$$
k_{3 D}=\frac{S F_{3 D}}{S F_{2 D}}=1.08 .
$$

Thus, the SF obtained on the basis of the stability reduction procedure in codes RS3 or PHASE2 (Rockscience) should be multiplied by the proposed correction coefficient.

Conclusions.

1. The paper represents a practical implementation of the approach combining numerical $3 \mathrm{D}$ simulation of the rock stress-strain state and stochastic representation of the rock properties to evaluate the pit wall stability in terms of the Kachar deposit (Kazakhstan). The safety factor of the pit wall was determined as 1.27 when the design contour was reached.

2. A finite element analysis and a procedure of step-by-step strength reduction provides the unambiguous evaluation of the rock slope stability in terms of changing the geometry of slopes at different mining stages. An area of the greatest shear strains obtained at each stage is the prototype of the potential slip surface. In case of deteriorating mining-geological conditions (namely, while operating within the zones of a geological fault and branch jointness), the zones of the greatest displacements obtained from the calculations will help forecast the rock mass volume, experiencing its transfer into the unstable state.

3 . The relationship between the safety factor of pit wall stability and the resulting slope angle, determined for the given conditions, is the important component of the forecast while substantiating technical solutions. Consideration of structural heterogeneity of rocks will help avoid unreasonably optimistic values of the slope safety factors that are of special importance while the development of steeply inclined ore deposits.

4. The performed computational experiment has substantiated the transfer coefficient that can correct the SF calculations in 2D models; that allows carrying out further multifactor calculations in the simplified 2D arrangement.

Acknowledgments. This work is funded by the Ministry of Education and Science of the Republic of Kazakhstan, grant No. AR08857087.

\section{References.}

1. Gumenik, I., \& Lozhnikov, O. (2015). Current condition of damaged lands by surface mining in Ukraine and its influence on environment. In New developments in mining engineering/Theoretical and practical solution of mineral resources mining, (pp. 139-145). London: Taylor \& Francis Group.

2. Moldabayev, S., Rysbaiuly, B., Sultanbekova, Z., \& Sarybayev, N. (2019). Methodological approach to creation of the 3D model of an 
oval-shaped open pit mine. E3S Web of Conferences, 123, 01049. https://doi.org/10.1051/e3sconf/201912301049.

3. Akdag, S., Basarir, H., Karpuz, C., \& Ozyurt, M. (2015). Stability Analysis and Optimized Slope Angle for the Iron Ore Open-Pit Mine. In Proceedings of $24^{\text {th }}$ International Mining Congress of Turkey: IMCET 15, 1, 1525. Retrieved from https://www.researchgate.net/publication/279182923_Stability_Analysis_and_Optimized_Slope_Angle for the Iron_Ore_Open-Pit_Mine.

4. Yang, J., Tao, Z., Li, B., Gui, Y., \& Li, H. (2012). Stability assessment and feature analysis of slope IN NANFEN open Pit iron mine. International Journal of Mining Science and Technology, 22(3), 329333. https://doi.org/10.1016/j.ijmst.2012.04.008.

5. Santos, T. B., Lana, M.S., Pereira, T. M., \& Canbulat, I. (2019). Quantitative hazard assessment system (Has-Q) for open pit mine slopes. International Journal of Mining Science and Technology, 29(3), 419-427. https://doi.org/10.1016/j.ijmst.2018.11.005.

6. Paradella, W. R., Ferretti, A., Mura, J.C., Colombo, D., Gama, F. F., Tamburini, A., ..., \& Gomes, L. L. (2015). Mapping surface deformation in open pit iron mines of Carajás Province (Amazon Region) using an integrated SAR analysis. Engineering Geology, 193, 61-78. https://doi.org/10.1016/j.enggeo.2015.04.015.

7. Hu, Y., Ren, F., Ding, H., Fu, Y., \& Tan, B. (2019). Study on the Process and Mechanism of Slope Failure Induced by Mining under Open Pit Slope: A Case Study from Yanqianshan Iron Mine, China. Advances in Civil Engineering, 2019, 1-26. https://doi. org/10.1155/2019/6862936

8. Tao, Z., Shu, Y., Yang, X., Peng, Y., Chen, Q., \& Zhang, H. (2020). Physical model test study on shear strength characteristics of slope sliding surface in Nanfen open-pit mine. International Journal of Mining Science and Technology, 30(3), 421-429. https://doi.org/10.1016/j. ijmst.2020.05.006.

9. Sdvyzhkova, O. O., Shashenko, O.M., \& Kovrov, O.S. (2010). Modelling of the rock slope stability at the controlled failure. Rock Mechanics in Civil and Environmental Engineering - Proceedings of the European Rock Mechanics Symposium - Switzerland: European Rock Mechanics Symposium, EUROCK 2010: 581-584.

10. Zhao, H., Tian, Y., Guo, Q., Li, M., \& Wu, J. (2020). The slope creep law for a soft rock in an open-pit mine in the Gobi region of Xinjiang, China. International Journal of Coal Science \& Technology, 7(2), 371-379. https://doi.org/10.1007/s40789-020-00305-4.

11. Zevgolis, I. E., Deliveris, A. V., \& Koukouzas, N. C. (2019). Slope failure incidents and other stability concerns in surface lignite mines in Greece. Journal of Sustainable Mining, 18(4), 182-197. https://doi. org/10.1016/j.jsm.2019.07.001.

12. Scoppettuolo, M.R., Cascini, L., \& Babilio, E. (2020). Typical displacement behavior of slope movements. Landslides, 17(5), 11051116. https://doi.org/10.1007/s10346-019-01327-z.

13. Zhang, X., Wang, L., Krabbenhoft, K., \& Tinti, S. (2019). A case study and implication: particle finite element modelling of the 2010 Saint-Jude sensitive clay landslide. Landslides, 17(5), 1117-1127. https://doi.org/10.1007/s10346-019-01330-4.

14. Nurić, A., \& Nurić, S. (2019). Numerical modeling of transport roads in open pit mines. Journal of Sustainable Mining, 18(1), 25-30. https://doi.org/10.1016/j.jsm.2019.02.005.

15. Roháč, J., Scaringi, G., Boháč, J., Kycl, P., \& Najser, J. (2019). Revisiting strength concepts and correlations with soil index properties: insights from the Dobkovičky landslide in Czech Republic. Landslides, 17(3), 597-614. https://doi.org/10.1007/s10346-019-01306-4. 16. Hongze, Z., Dongyu, W., Ming, M., \& Kaihui, Z. (2020). Parameter inversion and location determination of evolutionary weak layer for open-pit mine slope. International Journal of Coal Science \& Technology, 7(4), 714-724. https://doi.org/10.1007/s40789-020-00337-w.

17. Wei, Y., Hanhua, T., Jiandong, N., Wei, W., \& Xiaoyun, S. (2020). A new criterion for defining the failure of a fractured rock mass slope based on the strength reduction method. Geomatics, Natural Hazards and Risk, 11(1), 1849-1863.

18. Sdvyzhkova, O., Babets, D., Moldabayev, S., Rysbekov, K., \& Sarybayev, M. (2020). Mathematical modeling a stochastic variation of rock properties at an excavation design. International Multidisciplinary Scientific GeoConference Surveying Geology and Mining Ecology Management, SGEM, 165-172. https://doi.org/10.5593/sgem2020/1.2/s03.021.

19. Shcherbakov, P., Sarybayev, N., Tymchenko, S., Moldabayev, S., \& Bitimbayev, M. (2021). Mathematical model to optimize drillingand-blasting operations in the process of open-pit hard rock mining.
Mining of Mineral Deposits, 15(2), 25-34. https://doi.org/10.33271/ mining15.02.025.

20. Małkowski, P., Niedbalski, Z., \& Balarabe, T. (2021). Correction to: A statistical analysis of geomechanical data and its effect on rock mass numerical modeling: a case study. International Journal of Coal Science and Technology, 8(3), 457-458. https://doi.org/10.1007/ s40789-020-00378-1.

\section{Чисельне моделювання стійкості борту кар'єра на основі ймовірнісного підходу}

\author{
С. К. Молдабаєв ${ }^{1}$, О. О. Сдвижкова ${ }^{2}$, Д. В. Бабець ${ }^{2}$, \\ О. С. Ковров ${ }^{2}$, T. К. Аділь ${ }^{1}$
}

1 - Satbayev University, м. Алмати, Республіка Казахстан 2 - Національний технічний університет «Дніпровська політехніка», м. Дніпро, Україна, e-mail: sdvyzhkova.o.o@ nmu.one

Мета. Встановити закономірності зміни напруженодеформованого стану та стійкості борту кар'єру при виїмці залізної руди на різних етапах розвитку гірничих робіт при відпрацюванні крутоспадаючих пластів з урахуванням закономірних і стохастичних складових структурної неоднорідності породного масиву.

Методика. Чисельне 3D моделювання напружено-деформованого стану породного масиву, застосування процедури «зниження міцності» для визначення коефіцієнта запасу стійкості, облік неоднорідності середовища на основі стохастичної моделі.

Результати. Отримано розподіл максимальних деформацій зсуву й переміщень у масиві порід, що складають борт кар'єру, визначені потенційні поверхні ковзання й коефіцієнти запасу стійкості на різних етапах відпрацювання крутоспадаючого рудного пласта, виконана оцінка впливу структури масиву на стійкість борту, а також порівняння розрахунків на основі 3D і 2D моделей. Отримано коригувальний коефіцієнт, що дозволяє використовувати 2D модель для різноманітних розрахунків, побудована залежність коефіцієнта стійкості борту від результуючого кута укосу.

Наукова новизна. Встановлено, що при розробці крутоспадаючих залізорудних пластів поперечними панелями зверху вниз борт кар'єру зберігає експлуатаційну стійкість (коефіцієнт запасу стійкості (КЗС) становить не менше $1,27)$ незважаючи на збільшення глибини ведення гірничих робіт. Показано, що моделювання реальної геологічної будови тривимірної області породного масиву призводить до зменшення (на $7 \%$ ) значення коефіцієнта запасу стійкості в порівнянні з результатами однорідної моделі. Запропоновано ймовірнісно-статистичний підхід до врахування неоднорідності породного середовища, що дозволяє уникнути невиправдано оптимістичних прогнозів стійкості бортів кар'єру. Показано, що 3D моделювання дає К3С, що на $8 \%$ відрізняється від значень, отриманих у двовимірній моделі. Це дозволяє обгрунтувати поправочний коефіцієнт для коригування результатів 2D моделювання.

Практична значимість. Для гірничо-геологічних і гірничо-технічних умов Качарського родовища встановлена закономірність зміни стійкості борту кар'єру в залежності від результуючого кута укосу з урахуванням природної неоднорідності гірських порід.

Ключові слова: видобуток руди, глибокий кар'єр, стійкість борту, стохастичне середовище, чисельне моделювання, напружено-деформований стан породного масиву, коефіцієнт запасу стійкості

The manuscript was submitted 07.04.21. 